\title{
Psychological impact among health workers in effort to facing the COVID-19 in Indonesia
}

\author{
Dede Nasrullah $^{1}$, M. Natsir ${ }^{2}$, Retno Twistiandayani ${ }^{3}$, Lilis Rohayani ${ }^{4}$, Siswanto $^{5}$, Ni Made \\ Sumartyawati $^{6}$, Uswatun Hasanah ${ }^{7}$, Ade Herman Surya Direja ${ }^{8}$ \\ ${ }^{1,7}$ Faculty Health of Science, University Muhammadiyah of Surabaya, Indonesia \\ ${ }^{2}$ Department of Health Central Java Province, Indonesia \\ ${ }^{3}$ Faculty Health of Science, University of Gresik, Indonesia \\ ${ }^{4}$ Jenderal Achmad Yani Cimahi Institute of Health Sciences, Indonesia \\ ${ }^{5}$ Prof. Dr. Soerojo Mental Hospital Magelang, Indonesia \\ ${ }^{6}$ Mataram Institute of Health Sciences, Indonesia \\ ${ }^{8}$ Tri Mandiri Sakti Bengkulu Institute of Health Sciences, Indonesia
}

\begin{tabular}{l}
\hline Article Info \\
\hline Article history: \\
Received Jun 17, 2020 \\
Revised Dec 18, 2020 \\
Accepted Jan 2, 2021 \\
\hline
\end{tabular}

Keywords:

Health worker

Mental health

Pandemic

Psychological impact

\begin{abstract}
The coronavirus disease (COVID-19) pandemic in Indonesia has a psychological impact among health workers who are working in hospital and caring for patients with positive COVID-19. This study aimed to examines the psychological impact among health workers in effort to facing the coronavirus pandemic (COVID-19) in Indonesia. Snowball sampling technique was employed to gather the sample in the eight islands. The health workers were responded to the depression anxiety stress scales (DASS-42) questionnaire, with the total of 644 respondents. The results of this study showed that about $65.8 \%$ of respondents experienced anxiety due to COVID19 outbreak, There were $3.3 \%$ experienced extremely severe anxiety and $33.1 \%$ experienced mild anxiety. Whereas those experienced stress due to COVID-19 outbreak were 55\%, extremely severe stress levels were $0.8 \%$ and mild stress were $34.5 \%$. Health workers who experienced depression were $23.5 \%$. There were $0.5 \%$ with very severe depression and mild depression was $11.2 \%$. There is a closed correlation between anxiety $(\mathrm{r}=0.152 \mathrm{p}=0.000)$, stress $(\mathrm{r}=0.086 \mathrm{p}=0.029)$, and depression $(\mathrm{r}=0.111$ $\mathrm{p}=0.005$ ), to the worried of being alienated if infected coronavirus (COVID19). The Indonesian government has to handle the anxiety, stress and depression that occurs in health workers in particular and can provide protection to medical personnel so that they do not feel alienated by those around them.
\end{abstract}

This is an open access article under the $\underline{C C B Y-S A}$ license.

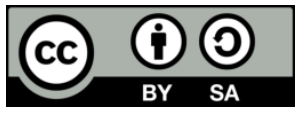

Corresponding Author:

Dede Nasrullah

Department of Nursing

University Muhammadiyah of Surabaya

Sutorejo Street 59 City Surabaya

Email: dedenasrullah@um-surabaya.ac.id

\section{INTRODUCTION}

On December 31, 2019, the WHO China Country Office reported a case of pneumonia of unknown etiology in Wuhan City, Hubei Province, China [1]. On January 7, 2020, China identified pneumonia as a new type of coronavirus (coronavirus disease, COVID-19) [2-3]. On 30 January 2020 WHO has designated the public health emergency of international concern (KKMMD/PHEIC) [4-5]. The increasing number of 
COVID-19 cases was quite quickly and there has been spreading across the countries [6]. As of March 25, 2020, a total of 414,179 confirmed cases with 18,440 deaths (CFR 4.4\%) were reported, which cases were reported in 192 countries/regions [7-9]. Among these cases, there were already several health workers who were reported infected [10-11]. On March 2, 2020, Indonesia reported two COVID-19 confirmed cases. As of March 25, 2020, Indonesia has reported 790 COVID-19 confirmed cases from 24 Provinces: Bali, Banten, DIY, DKI Jakarta, Jambi, West Java, Central Java, East Java, West Kalimantan, East Kalimantan, Central Kalimantan, South Kalimantan, Riau Islands, West Nusa Tenggara, South Sumatra, North Sumatra, North Sulawesi, Southeast Sulawesi, South Sulawesi, Lampung, Riau, North Maluku, Maluku and Papua. Areas with local transmissions in Indonesia are DKI Jakarta, Banten (Tangerang Regency, Tangerang City), West Java (Bandung City, Bekasi Regency, Bekasi City, Depok City, Bogor Regency, Bogor City, Karawang Regency), Java East (Malang Regency, Magetan Regency and Surabaya City) and Central Java (Surakarta City) [12].

Pandemic of COVID-19 outbreak causes feeling worried, and understanding of mental health status is urgently needed for the community $[13,14]$. Previous research has stated that deep and a broad of psychological impact on level of individual, community, and international during an outbreak of infection [15]. On the individual level, people tend to experience worried of being sick or dying, feelings of helplessness, and stigma [16, 17]. In China the results of the study stated $53.8 \%$ had a positive effect on psychological impact as a moderate or severe outbreak; $16.5 \%$ reported symptoms of moderate to severe depression; $28.8 \%$ reported symptoms of moderate to severe anxiety; and $8.1 \%$ reported moderate to severe stress levels [18]. They were older, female, more highly educated, with a higher risk perception of severe acute respiratory syndrome (SARS), lower levels of anxiety, contact history, and with it similar symptoms SARS is more likely to take precautionary measures against infection [3]. Besides, Lijung et al. Strengthened that service providers such as health workers affected by virus in Wuhan experienced psychological health disorders [19]. Work-related stress is a potential cause for health workers. It is associated with anxiety including various activities both depression to face death in the growing society, long work shift, and a lot of work demands in dealing with COVID-19 patients, those are important indicator of psychological fatigue [20, 21]. Health workers are influential and needed during the COVID-19 outbreak and they are one of the most vulnerable to contracting this very deadly disease.

The experience of health workers in dealing with COVID-19 has many effects on mental health stress, anxiety, and depression. It is not only experienced in the short term but also has a long-term impact and the value of effective support [22]. It is necessary to take an effective action in a timely manner to address and protect the mental health of health workers. Based on previous research related to middle eastern respiratory syndrome (MERS), health workers tend to believe that such actions help protect mental health [23]. In addition, to reduce psychological damage to health workers, both nurses, doctors and other health workers, Indonesian government needs to provide a program so that this research becomes a reference in making the program.

Therefore this study aimed to examines the psychological impact among community in effort to facing the coronavirus pandemic (COVID-19) in Indonesia. This study also aimed to determine the prevalence of symptoms, stress risk factors, anxiety and depression in maintaining the psychological wellbeing of people in Indonesia.

\section{RESEARCH METHOD}

\subsection{Respondent}

The online survey was conducted among health worker in Indonesia which was divided into several regions namely Java and the islands, Sumatra and the islands, Kalimantan, Sulawesi, Bali, Nusa Tenggara, Maluku and Papua, then they were encouraged to share it with others.

\subsection{Data collection}

This study used a cross-sectional survey design to determine psychological responses during the COVID-19 pandemic by using questionnaires through online anonymously. Sampling technique in this study uses snowball to the community and health workers during the COVID-19 pandemic.

\subsection{Procedure}

When the Indonesian government announced to the public of Indonesia to do social distancing then the researcher invited prospective respondents to fill out a questionnaire through Google Form, before that the researchers were doing validity and reliability test of the questionnaire. The results of the validity test show the value of r-table 0.254 is smaller than the value of r-count which means valid, and reliability using Cronbach's alpha shows the value of 0.958 meaning reliable. Respondent who gave feedback were 644 . Data collection was carried out for seven days (01-07 April 2020) distributed to eight islands in Indonesia covering 
Java, Sumatra, Kalimantan, Sulawesi, Bali, Nusa Tenggara, Papua and Maluku after the President of Indonesia declared COVID-19 outbreak as a health emergency and was a concern of the Indonesian government.

\subsection{Instrument}

Mental health status was measured uses the Depression, Anxiety and Stress Scale (DASS-42) and the score calculation was based on previous research. Questions 1, 3, 5, 8, 13, 14, 15, 20, 24, 35, 36, 40, 41, and 42 form the stress subscale. Subscale scores of total depression are divided into normal (0-10), mild stress (11-18), moderate stress (19-26), severe stress (27-34), and extremely severe stress (35-42). Questions $4,9,11,12,18,19,25,29,30,32,34,37,38$, and 39 form the anxiety subscale. The total anxiety subscale score is divided into normal (0-6), mild anxiety (7-9), moderate anxiety (10-14), severe anxiety (15-19), and extremely severe anxiety (20-42). Questions 2, 6, 7, 10, 16, 17, 21, 22, 23, 26, 27, 28, 31, and 32 form the depression subscale. The total depression subscale score is divided into normal (0-9), mild depression (1012), moderate depression (13-20), severe depression (21-27), and extremely severe depression (28-42). DASS was previously used in research related to severe acute respiratory syndrome (SARS).

\subsection{Analysis test}

Descriptive statistics are used to calculate sociodemographic characteristics, while univariate tests were used to find the relationship of social responses with levels of anxiety, stress and depression to the coronavirus pandemic (COVID-19) uses the spearman rank with a significance level of $\mathrm{p}<0.005$ and uses a simple multivariate linear regression SPPS 21.

\section{RESULTS}

\subsection{Development of the COVID-19 pandemic from 01 March-10 April 2020}

Figure 1 shows the development trend of the coronavirus pandemic (COVID-19) in Indonesia from March and April 27, 2020 totaling cases 9096 [24], on April 1, 2020 the Indonesian government announced a state of health emergency. The number of confirmed cases, positive, people recovered, and death cases continue to increase.

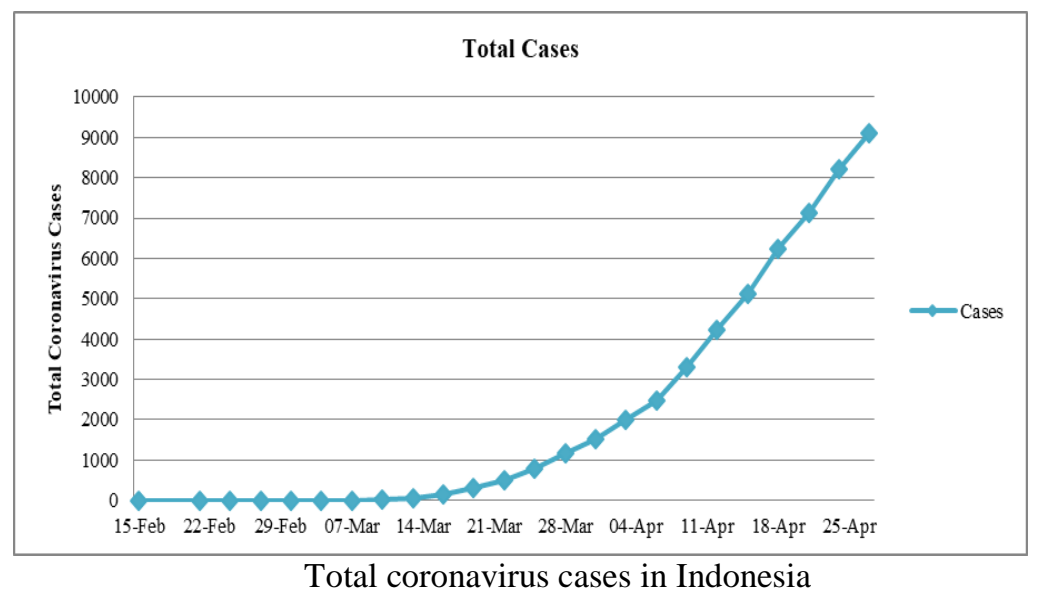

Figure 1. Cases of the coronavirus pandemic (COVID-19) in Indonesia from March to April, 2020

\subsection{Characteristics of respondents based on gender, age, domicile, occupation, education, income}

Table 1 shows the characteristics of respondents which included gender, age, domicile, occupation, education and income. Among the 644 samples the most gender was female 484 (74.2\%) compared to 160 male respondents $(24.8 \%)$. The majority of respondents were from Java Island with $1372(60.7 \%)$.

\subsection{The psychological impact among health in effort to facing the coronavirus pandemic (COVID-19) in Indonesia}

Table 2 shows data related to the psychological impact anxiety among health workers in effort to facing the coronavirus pandemic (COVID-19) from a total of 664 respondents of health workers, there were $213(33.1 \%)$ with mild anxiety and there were $21(3.3 \%)$ very severe anxiety. Table 3 reveals data related to the psychological impact stress among health workers in effort to facing the coronavirus pandemic (COVID- 
19), the data showed that respondents mild stress 222 and extremely severe stress level five (0.8\%). Table 4 shows data related to the psychological impact of depression on health workers in an effort to deal with the coronavirus pandemic (COVID-19), as many as 72 respondents (11.2\%) experienced mild depression and very severe depression three $(0.5 \%)$.

Table 1. Characteristics of respondents

\begin{tabular}{ccc}
\hline Variable & Total & Percentage (\%) \\
\hline Gender & 160 & 24.8 \\
Male & 484 & 75.2 \\
Female & & \\
Age & 208 & 32.3 \\
$20-29$ & 252 & 39.1 \\
$30-39$ & 154 & 23.9 \\
$40-49$ & 30 & 4.7 \\
$>50$ & & \\
Domicile & & 10.7 \\
Sumatera and islands & 69 & 67.7 \\
Java and islands & 436 & 12.4 \\
Bali and Nusa Tenggara & 80 & 2.6 \\
Kalimantan & 17 & 4.5 \\
Sulawesi & 29 & 14.4 \\
Maluku and Papua & 13 & \\
Education & & 26.7 \\
Senior High school & 19 & 17 \\
Diploma & 225 & 42,2 \\
S1/Bachelor & 319 & 11.7 \\
S2/Postgraduate & 80 & 0.7 \\
S3/Doctor & 1 & \\
Income (IDR) & & 0.5 \\
<500,000 & 3 & 1.7 \\
500,000-<1,000,000 & 11 & 7 \\
1,000,000-<1,500,000 & 23 & 3.6 \\
1,500,000-<2,000,000 & 45 & 9.6 \\
<2,000,000 & 63 & 78 \\
& 502 & \\
\hline & & \\
\hline
\end{tabular}

Table 2. Univariate data of the psychological impact anxiety among health workers in effort to facing the coronavirus pandemic (COVID-19)

\begin{tabular}{|c|c|c|c|c|c|c|c|}
\hline \multirow[b]{2}{*}{ Variable } & \multicolumn{4}{|c|}{ Anxiety levels } & \multirow[b]{2}{*}{ Extremely severe } & \multirow[b]{2}{*}{ Statistic } & \multirow[b]{2}{*}{$\mathrm{p}$} \\
\hline & Normal & Mild & Moderate & Severe & & & \\
\hline \multicolumn{8}{|l|}{ Gender } \\
\hline Male & $69(43.1)$ & $49(30.6)$ & $28(17.5)$ & $10(6.2)$ & $4(2.5)$ & 0.103 & 0.009 \\
\hline Female & $152(31.4)$ & $164(33.9)$ & $120(24.8)$ & $31(6.4)$ & $17(3.5)$ & & \\
\hline \multicolumn{8}{|l|}{ Age } \\
\hline $20-29$ & $55(26.2)$ & $74(35.2)$ & $58(27.6)$ & $14(6.7)$ & $9(4.3)$ & \multirow{4}{*}{-0.136} & \multirow{4}{*}{0.001} \\
\hline $30-39$ & $89(35.6)$ & $80(32)$ & $55(22)$ & $16(6.4)$ & $10(4)$ & & \\
\hline $40-49$ & $63(40.9)$ & $50(32.5)$ & $30(19.5)$ & $9(5.8)$ & $2(1.3)$ & & \\
\hline$>50$ & $14(46.7)$ & $9(30)$ & $5(16.7)$ & $2(6.7)$ & $0(0)$ & & \\
\hline \multicolumn{8}{|l|}{ Domicile } \\
\hline $\begin{array}{l}\text { Sumatera and islands } \\
\text { Java and islands }\end{array}$ & $19(27.5)$ & $24(34.8)$ & $21(30.4)$ & $2(2.9)$ & $3(4.3)$ & \multirow{7}{*}{0.042} & \multirow{7}{*}{0.289} \\
\hline Bali and Nusa Tenggara & $166(38.1)$ & $136(31.2)$ & $96(22)$ & $28(6.4)$ & $10(2.3)$ & & \\
\hline Kalimantan & $20(25)$ & $30(37.5)$ & $20(25$ & $6(7.5)$ & $4(5)$ & & \\
\hline Sulawesi & & & & & & & \\
\hline \multirow[t]{3}{*}{ Maluku and Papua } & $4(23.5)$ & $9(52.9)$ & $1(5.9)$ & $0(0)$ & $3(17.6)$ & & \\
\hline & $5(17.2)$ & $12(41.4)$ & $7(24.1)$ & $4(13.8)$ & $1(3.4)$ & & \\
\hline & $7(53.8)$ & $2(15.4)$ & $3(23.1)$ & $1(7.7)$ & $0(0)$ & & \\
\hline Education & & & & & & \multirow{6}{*}{-0.097} & \multirow{6}{*}{0.014} \\
\hline Senior High School & $5(27.8)$ & $8(44.4)$ & $4(22.2)$ & $1(5.6)$ & $0(0)$ & & \\
\hline Diploma & $71(31.7)$ & $71(31.7)$ & $59(26.3)$ & $16(7.1)$ & $7(3.1)$ & & \\
\hline S1/ Bachelor & $105(32.7)$ & $108(33.6)$ & $73(22.7)$ & $22(6.9)$ & $13(4)$ & & \\
\hline S2/ Postgraduate & $40(50)$ & $25(31.2)$ & $12(15)$ & $2(2.5)$ & $1(1.2)$ & & \\
\hline S3/Doctor & $9(56.2)$ & $5(31.2)$ & $1(6.2)$ & $0(0)$ & $1(6.2)$ & & \\
\hline \multicolumn{8}{|l|}{ Income (IDR) } \\
\hline$<500,000$ & $2(16.7)$ & $4(33.3)$ & $5(41.7)$ & $1(8.3)$ & $0(0)$ & \multirow{5}{*}{-0.179} & \multirow{5}{*}{0.000} \\
\hline $500,000-<1,000,000$ & $7(30.4)$ & $6(26.1)$ & $5(21.7)$ & $3(13)$ & $2(8.7)$ & & \\
\hline $1,000,000-<1,500,000$ & $8(17.8)$ & $15(33.3)$ & $17(37.8)$ & $3(6.7)$ & $2(4.4)$ & & \\
\hline $1,500,000-<2,000,000$ & $12(19.7)$ & $21(34.4)$ & $19(31.1)$ & $4(6.6)$ & $5(8.2)$ & & \\
\hline$\geq 2,000,000$ & $192(38.2)$ & $167(33.2)$ & $105(20.3)$ & $30(6)$ & $12(2.4)$ & & \\
\hline
\end{tabular}


Tabel 3. Univariate data of the psychological impact stress among health workers in effort to facing the coronavirus pandemic (COVID-19)

\begin{tabular}{|c|c|c|c|c|c|c|c|}
\hline \multirow{2}{*}{ Variable } & \multicolumn{7}{|c|}{ Stress Levels } \\
\hline & Normal & Mild & Moderate & Severe & Extremely severe & Statistic & $\mathrm{p}$ \\
\hline \multicolumn{8}{|l|}{ Gender } \\
\hline Male & $81(50.6)$ & $54(33.8)$ & $20(12.5)$ & $4(2.5)$ & $1(0.6)$ & \multirow[t]{2}{*}{0.075} & \multirow[t]{2}{*}{0.057} \\
\hline Female & $209(43.2)$ & $168(34.7)$ & $91(18.8)$ & $12(2.5)$ & $4(0.8)$ & & \\
\hline \multicolumn{8}{|l|}{ Age } \\
\hline $20-29$ & $87(42.4)$ & $75(35.7)$ & $41(19.5)$ & $7(3.3)$ & $0(0)$ & \multirow{4}{*}{-0.110} & \multirow{4}{*}{0.005} \\
\hline $30-39$ & $103(41.2)$ & $89(35.6)$ & $45(18)$ & $9(3.6)$ & $4(1.6)$ & & \\
\hline $40-49$ & $82(53.2)$ & $48(31.2)$ & $23(14.9)$ & $0(0)$ & $1(0.6)$ & & \\
\hline$>50$ & $18(60)$ & $10(33.3)$ & $2(6.7)$ & $0(0)$ & $0(0)$ & & \\
\hline \multicolumn{8}{|l|}{ Domicile } \\
\hline $\begin{array}{c}\text { Sumatera dan kepulauan } \\
\text { Jawa dan kepulauan }\end{array}$ & $29(42)$ & $29(42)$ & $9(13)$ & $1(1.4)$ & $1(1.2)$ & \multirow{7}{*}{0.042} & \multirow{7}{*}{0.289} \\
\hline Bali dan Nusa Tenggara & $208(47.7)$ & $148(33.9)$ & $66(15.1)$ & $12(2.8)$ & $2(0.5)$ & & \\
\hline Kalimantan & $30(37.5)$ & $25(31.2)$ & $25(31.2)$ & $0(0)$ & $0(0)$ & & \\
\hline Sulawesi & & & & & & & \\
\hline \multirow{3}{*}{ Maluku dan Papua } & $8(47.1)$ & $5(29.4)$ & $1(5.9)$ & $1(5.9)$ & $2(11.8)$ & & \\
\hline & $8(27.6)$ & $13(44.8)$ & $7(24.1)$ & $1(3.4)$ & $0(0)$ & & \\
\hline & $7(53.8)$ & $2(15.4)$ & $3(23.1)$ & $1(7.7)$ & $0(0)$ & & \\
\hline Education & & & & & & \multirow{6}{*}{-0.061} & \multirow{6}{*}{0.122} \\
\hline SMA/Sederajat & $3(16.7)$ & $7(38.9)$ & $7(38.9)$ & $1(5.6)$ & $0(0)$ & & \\
\hline Diploma & $104(46.4)$ & $82(36.6)$ & $32(14.3)$ & $3(1.3)$ & $3(1.3)$ & & \\
\hline $\mathrm{S} 1$ & $135(42.1)$ & $107(33.3)$ & $66(20.6)$ & $11(3.4)$ & $2(0.6)$ & & \\
\hline $\mathrm{S} 2$ & $47(58.8)$ & $26(32.5)$ & $6(7.5)$ & $1(1.2)$ & $0(0)$ & & \\
\hline S3 & $1(100)$ & $0(0)$ & $0(0)$ & $0(0)$ & $0(0)$ & & \\
\hline \multicolumn{8}{|l|}{ Income (IDR) } \\
\hline$<500,000$ & $2(16.7)$ & $5(41.7)$ & $5(41.7)$ & $0(0)$ & $0(0)$ & \multirow{5}{*}{-0.179} & \multirow{5}{*}{0.000} \\
\hline $500,000-<1,000,000$ & $10(43.5)$ & $6(26.1)$ & $6(26.1)$ & $1(4.3)$ & $0(0)$ & & \\
\hline $1,000,000-<1,500,000$ & $8(17.8)$ & $15(33.3)$ & $17(37.8)$ & $3(6.7)$ & $2(4.4)$ & & \\
\hline $1,500,000-<2,000,000$ & $12(19.7)$ & $21(34.4)$ & $19(31.1)$ & $4(6.6)$ & $5(8.2)$ & & \\
\hline$\geq 2,000,000$ & $242(48.1)$ & $176(35)$ & $71(14.1)$ & $11(2.2)$ & $3(0.6)$ & & \\
\hline
\end{tabular}

Tabel 4. Univariate data of the psychological impact depression among health workers in effort to facing the coronavirus pandemic (COVID-19)

\begin{tabular}{|c|c|c|c|c|c|c|c|}
\hline \multirow[b]{2}{*}{ Variable } & \multicolumn{4}{|c|}{ Depression levels } & \multirow[b]{2}{*}{ Extremely severe } & \multirow[b]{2}{*}{ Statistic } & \multirow[b]{2}{*}{$\mathrm{p}$} \\
\hline & Normal & Mild & Moderate & Severe & & & \\
\hline \multicolumn{8}{|l|}{ Gender } \\
\hline Male & $129(80.6)$ & $14(8.8)$ & $16(10)$ & $0(0)$ & $1(0.6)$ & \multirow{3}{*}{0.053} & \multirow[t]{2}{*}{0.180} \\
\hline Female & $364(75.2)$ & $58(12)$ & $60(12.4)$ & $0(0)$ & $2(0.4)$ & & \\
\hline \multicolumn{7}{|l|}{ Age } & \\
\hline $20-29$ & $151(71.9)$ & $28(13.3)$ & $29(13.8)$ & $0(0)$ & $2(1)$ & \multirow{4}{*}{-0.075} & \multirow{4}{*}{0.058} \\
\hline $30-39$ & $194(77.6)$ & $27(10.8)$ & 29 (11.6) & $0(0)$ & $0(0)$ & & \\
\hline $40-49$ & $126(81.8)$ & $13(8.4)$ & $14(9.1)$ & $0(0)$ & $1(0.6)$ & & \\
\hline$>50$ & $22(73.3)$ & $4(13.3)$ & $4(13.3)$ & $0(0)$ & $0(0)$ & & \\
\hline \multicolumn{8}{|l|}{ Domicile } \\
\hline $\begin{array}{l}\text { Sumatera and islands } \\
\text { Java and islands }\end{array}$ & $53(76.8)$ & $8(11.6)$ & $8(11.6)$ & $0(0)$ & $0(0)$ & \multirow{6}{*}{0.054} & \multirow{6}{*}{0.169} \\
\hline Bali and Nusa Tenggara & $342(78.4)$ & $43(9.9)$ & $48(11)$ & $0(0)$ & $3(0.7)$ & & \\
\hline $\begin{array}{c}\text { Kalimantan } \\
\text { Sulawesi }\end{array}$ & $55(68.8)$ & $16(20)$ & $9(11.2)$ & $0(0)$ & $0(0)$ & & \\
\hline \multirow{3}{*}{ Maluku and Papua } & $12(70.6)$ & $1(5.9)$ & $4(23.5)$ & $0(0)$ & $0(0)$ & & \\
\hline & $21(72.4)$ & $3(10.3)$ & $6(17.2)$ & $0(0)$ & $0(0)$ & & \\
\hline & $10(76.9)$ & $1(7.7)$ & $2(15.4)$ & $0(0)$ & $0(0)$ & & \\
\hline Education & & & & & & & \\
\hline Senior High School & $12(66.7)$ & $3(16.7)$ & $3(16.7)$ & $0(0)$ & $0(0)$ & \multirow{5}{*}{-0.123} & \multirow{5}{*}{0.002} \\
\hline Diploma & $161(71.9)$ & $29(12.9)$ & $33(14.7)$ & $0(0)$ & $1(0.4)$ & & \\
\hline S1/ Bachelor & $247(76.9)$ & $3811.8)$ & $34(10.6)$ & $0(0)$ & $2(0.6)$ & & \\
\hline S2/ Postgraduate & $72(90)$ & $2(2.5)$ & $6(7.5)$ & $0(0)$ & $0(0)$ & & \\
\hline S3/Doctor & $1(100)$ & $0(0)$ & $0(0)$ & $0(0)$ & $0(0)$ & & \\
\hline \multicolumn{8}{|l|}{ Income (IDR) } \\
\hline$<500,000$ & $8(66.7)$ & $2(16.7)$ & $2(16.7)$ & $0(0)$ & $0(0)$ & \multirow{5}{*}{-0.159} & \multirow{5}{*}{0.000} \\
\hline $500,000-<1,000,000$ & $15(65.2)$ & $4(17.4)$ & $4(17.4)$ & $0(0)$ & $0(0)$ & & \\
\hline $1,000,000-<1,500,000$ & $33(73.3)$ & $4(8.9)$ & $8(17.8)$ & $0(0)$ & $0(0)$ & & \\
\hline $1,500,000-<2,000,000$ & $33(54.1)$ & $14(23)$ & $12(19.7)$ & $0(0)$ & $2(3.3)$ & & \\
\hline$\geq 2.000 .000$ & $404(80.3)$ & $48(9.5)$ & $50(9.9)$ & $0(0)$ & $1(0.2)$ & & \\
\hline
\end{tabular}

Correlation of social responses among health workers in effort to facing the coronavirus pandemic (COVID-19) (Worried loss of livelihood, Worried of Alienation, Worried of infected and infecting) 
Correlation analysis were shown in Table 5 associated with panic when hearing information from online media $(r=0.248, p$ 0.000), and worry of being alienated $(r=0.152, p 0.000)$ the correlation coefficient was quite strong on the level of anxiety. Besides, worrying become contagious ( $r=0.112, p$ 0.004), and worry being excluded $(\mathrm{r}=0.111, \mathrm{p} 0.005)$ the correlation coefficient was quite strong on the level of depression.

\section{Simple Linear Regression Analysis}

Table 6 showed a simple linear regression analysis of social responses among health workers in effort to facing the coronavirus pandemic (COVID-19), the social responses that most influence on anxiety, stress and depression are people panic while listening to information from online media with the results of anxiety $\left(\mathrm{R}^{2} 0.058, \mathrm{AR}^{2} 0.057, \mathrm{~B}(95 \% \mathrm{CI}) 0.242\right)$, stress $\left(\mathrm{R}^{2} 0.040, \mathrm{AR}^{2} 0.038, \mathrm{~B}(95 \% \mathrm{CI}) 0.199\right)$ and depression $\left(\mathrm{R}^{2} 0.014, \mathrm{AR}^{2} 0.013, \mathrm{~B}(95 \% \mathrm{CI}) 0.120\right)$.

Table 5. Correlations of social responses among health workers in effort to facing the coronavirus pandemic (COVID-19)

\begin{tabular}{|c|c|c|c|c|c|c|}
\hline \multirow{2}{*}{ Social Responses } & \multicolumn{2}{|c|}{ Anxiety } & \multicolumn{2}{|c|}{ Stress } & \multicolumn{2}{|c|}{ Depression } \\
\hline & $\mathrm{R}$ & $\mathrm{p}$ & $\mathrm{R}$ & $\mathrm{p}$ & $\mathrm{R}$ & $\mathrm{p}$ \\
\hline Worried of being infected and infecting & 0.079 & 0.046 & 0.002 & 0.952 & 0.007 & 0.863 \\
\hline Worried of being alienation & 0.152 & 0.000 & 0.086 & 0.029 & 0.111 & 0.005 \\
\hline $\begin{array}{l}\text { Panic while listening to information from online media } \\
\text { (television, radio, newspaper and other media) }\end{array}$ & 0.248 & 0.000 & 0.199 & 0.000 & 0.112 & 0.004 \\
\hline
\end{tabular}

${ }^{\mathrm{r}}$ Coefficient correlation

Table 6. Simple linear regression analysis of social responses among health workers in effort to facing the coronavirus pandemic (COVID-19)

\begin{tabular}{|c|c|c|c|c|c|c|c|c|c|}
\hline \multirow{2}{*}{ Social response } & \multicolumn{3}{|c|}{ Anxiety } & \multicolumn{3}{|c|}{ Stress } & \multicolumn{3}{|c|}{ Depression } \\
\hline & $\mathrm{R}^{2}$ & $\mathrm{AR}^{2}$ & $\mathrm{~B}(95 \% \mathrm{CI})$ & $\mathrm{R}^{2}$ & $\mathrm{AR}^{2}$ & $\mathrm{~B}(95 \% \mathrm{CI})$ & $\mathrm{R}^{2}$ & $\mathrm{AR}^{2}$ & $\mathrm{~B}(95 \% \mathrm{CI})$ \\
\hline Worried of being infected and infecting & 0.004 & 0.003 & 0.066 & 0.000 & $0 . \overline{-}$ & 0.002 & 0.12 & $0 . \overline{-}$ & 0.110 \\
\hline Worried of being alienation & 0.021 & 0.019 & 0.114 & 0.008 & 0.007 & 0.091 & 0.009 & 0.008 & 0.096 \\
\hline $\begin{array}{c}\text { panic while listening to information from } \\
\text { online media (television, radio, } \\
\text { newspaper and other media) }\end{array}$ & 0.058 & 0.057 & 0.242 & 0.040 & 0.038 & 0.199 & 0.014 & 0.013 & 0.120 \\
\hline
\end{tabular}

\section{DISCUSSION}

Coronavirus has many impacts on the psychological response of the health workers. This study showed that $65.8 \%$ respondents of health workers in Indonesia experienced anxiety due to the COVID-19 outbreak, there were $3.3 \%$ experienced extremely severe anxiety and $33.1 \%$ experienced mild anxiety. Health workers who working in hospital that caring of patients with COVID-19 stated more experienced psychological disorders and almost two times had the risk of experiencing anxiety disorders than non-clinical staff [25]. Whereas those experienced stress due to the COVID-19 outbreak were 55\%, extremely severe stress levels were $0.8 \%$ and mild stress were $34.5 \%$. Health workers who experienced depression were $23.5 \%$. Extremely severe depression rate $0.5 \%$ and mild depression $11.2 \%$.

Generally known that SARS-CoV-2 is very contagious and spreads rapidly, health workers in the frontline had a risk to be infected so that significantly increasing the workload. In addition they are afraid of bringing the virus to their families and inability of health workers to deal with critical patients [26]. The more burdens of health workers, the greater they will not be able to do their duty, it can caused anxiety and stress $[16,19]$.

The results of this study showed that there is a closed correlation between anxiety ( $\mathrm{r}=0.152$ $\mathrm{p}=0.000)$, stress $(\mathrm{r}=0.086 \mathrm{p}=0.029)$, and depression $(\mathrm{r}=0.111 \mathrm{p}=0.005)$ and depression $(\mathrm{r}=0.111 \mathrm{p}=0.005)$, to the worried of being alienated if infected coronavirus. The more obstacles they experienced the greater they are unable to achieve their aspirations. Then there will be tension in themselves and caused anxiety and stress $[25,27]$. As we know that in China, health workers are striving as the frontline to fight coronavirus and protect people $[28,29]$.

Based on result of simple linear regression analysis test on social responses among health workers in effort to facing the coronavirus pandemic (COVID-19), the social responses that most influence on anxiety, stress and depression are people panic while listening to information from online media with the results of anxiety $\left(\mathrm{R}^{2} 0.058, \mathrm{AR}^{2} 0.057, \mathrm{~B}(95 \% \mathrm{CI})\right.$ 0.242), stress $\left(\mathrm{R}^{2} 0.040, \mathrm{AR}^{2} 0.038, \mathrm{~B}(95 \% \mathrm{CI}) 0.199\right)$ and depression $\left(\mathrm{R}^{2} 0.014, \mathrm{AR}^{2} 0.013\right.$, B (95\% CI) 0.120). The Indonesian government has provided of health workers a place for lodging and even provide food and vitamins for health workers to reduce the

Int. J. Public Health Sci. Vol. 10, No. 1, March 2021: 181 - 188 
psychological impact. Every hospital is very important to help overcome the problem of tension that occurs in health workers that include anxiety, stress and depression responses.

In addition to the fear of transmitting the infection to colleagues and family members coupled with the dilemma of applying for sick leave in an already strained healthcare sector, many healthcare workers develop burnout and may experience a sense of intense fear, stigmatization and ostracism when displaying physical symptoms suggestive of the virus infection, which often leads to negative psychological pain [30, 31]. This phenomenon has already been described in the studies during the current COVID-19 outbreak [28] as well as previous Ebola crisis [32]. In addition, research conducted at the time of the SARS outbreak showed that health workers who worked in emergency rooms had a higher risk of experiencing post-traumatic stress disorder (PTSD) compared to health workers who were in wards [33]. Health workers in an emergency were at a higher risk for developing post traumatic stress disorder [34].

This research can be a reference to the Indonesian government to handle anxiety, stress and depression that occur in health workers in particular and can provide protection to medical personnel so that they do not feel alienated by those around them. In addition, the government must provide full support to health workers as the frontline in handling COVID-19 in Indonesia.

Our research also has some limitations. First, compared with face to face interviews, self-reporting has certain limitations. Second, the study is cross-sectional and does not track the efficacy of psychological services. Due to changes in posttraumatic mental health, dynamic observation is necessary. A randomized prospective study could better determine correlation and causation. Third, a larger sample size is needed to verify the results.

\section{CONCLUSION}

About $65.8 \%$ respondents of health workers in Indonesia experienced anxiety due to COVID-19 outbreak 19, there were $3.3 \%$ experienced extremely severe anxiety and $33.1 \%$ experienced mild anxiety. While 55\% of health workers experienced stress due to COVID-19 outbreak, extremely severe stress levels were $0.8 \%$ and experienced mild stress $34.5 \%$. Health workers who experienced depression were $23.5 \%$. Severe depression is $0.5 \%$ while mild depression is $11.2 \%$.

The results of this study showed that there is a closed correlation between anxiety ( $r=0.152$ $\mathrm{p}=0.000)$, stress $(\mathrm{r}=0.086 \mathrm{p}=0.029)$, and depression $(\mathrm{r}=0.111 \mathrm{p}=0.005)$, to the worried of being alienated if infected coronavirus. We recommend to the Indonesian government must handle the anxiety, stress and depression that occurs in health workers in particular and can provide protection to medical personnel so that they do not feel alienated by those around them.

\section{ACKNOWLEDGEMENTS}

We gratefully acknowledge the support of the Muhammadiyah University of Surabaya, University of Gresik, Jenderal Achmad Yani Cimahi Institute of Health Sciences, Mataram Institute of Health Sciences, Tri Mandiri Sakti Bengkulu Institute of Health Sciences.

\section{REFERENCES}

[1] P. W. H. Chen Wang., F. G. Hayden., and G. F. Gao, "A novel coronavirus outbreak of global health concern," Lancet, vol. 396, no. 10223, pp. 470-473, 2020.

[2] K. Liu, et al., "Clinical characteristics of novel coronavirus cases in tertiary hospitals in Hubei Province," Chin. Chinese Medical Journa., vol. 133, no. 9, pp. 1025-1031, 2020.

[3] A. . Nishiura, et al., "The Extent of Transmission of Novel Coronavirus in Wuhan, China, 2020," Journal Clinical Medicine, vol. 9, no. 2, p. 330, 2020, doi: https://doi.org/10.3390/jcm9020330.

[4] P. H. Deng SQ, "Characteristics of and Public Health Responses to the Coronavirus Disease 2019 Outbreak in China," J Clin Med., vol. 9, no. 2, 2020.

[5] A. Al-Rabiaah et al., "Middle East Respiratory Syndrome-Coronavirus (MERS-CoV) associated stress among medical students at a university teaching hospital in Saudi Arabia," JoirnalInfectious Public Health, vol. 13, no. 5, pp. 687-691, 2020, doi: https://doi.org/10.1016/j.jiph.2020.01.005.

[6] P. Chen, L. Mao., G. P. Nassis., P. Harmer., B. E. Ainsworth., and F. Li, "Wuhan coronavirus (2019-nCoV): The need to maintain regular physical activity while taking precautions," Journal Sport Health Science, vol. 9, no. 2, pp. 103-104, 2020, doi: 10.1016/j.jshs.2020.02.001.

[7] W. H. Organization, "Emergencies: Novel coronavirus 2019," Geneva: WHO, 2020.

[8] M. Catharine I. Paules, et al., "Coronavirus Infections-More Than Just the Common Cold," JAMA., vol. 323, no. 8, pp. 707-708, 2020, doi:10.1001/jama.2020.0757.

[9] S. Zhao et al., "Estimating the Unreported Number of Novel Coronavirus ( 2019-nCoV ) Cases in China in the First Half of January 2020: A Data-Driven Modelling Analysis of the Early Outbreak," Journal Clinical Medicine, vol. 9, no. 2, p. 388, 2020, doi: https://doi.org/10.3390/jcm9020388. 
[10] Mahase Elisabeth, "China coronavirus: WHO declares international emergency as death toll exceeds 200," BMJ, vol. 368, 2020, doi: https://doi.org/10.1136/bmj.m408.

[11] R. Lu, "Genomic characterisation and epidemiology of 2019 novel coronavirus: implications for virus origins and receptor binding," Lancet Psh., vol. 395, vol. 10224, pp. 565-574, 2020, doi: https://doi.org/10.1016/S01406736(20)30251-8.

[12] Kementerian Kesehatan Republik Indonesia, "Guidelines for the Prevention and Control of Coronavirus Disease (COVID-19) Revision 4/Pedoman Pencegahan dan Pengendalian Coronavirus Disease (COVID-19) Revisi 4," Jakarta: Kementrian Kesehatan RI, 2020.

[13] Y.-T. Xiang, et al., "Timely mental health care for the 2019 novel coronavirus outbreak is urgently needed," Comment., vol. 7, no. 3, pp. 228-229, 2020, doi: https://doi.org/10.1016/S2215-0366(20)30046-8.

[14] B. Tang, N. L. Bragazzi, Q. Li, S. Tang, et al., "An updated estimation of the risk of transmission of the novel coronavirus (2019-nCov)," Infectious Disease Modelling, vol. 5, pp. 248-255, 2020. https://doi.org/10.1016/j.idm.2020.02.001.

[15] W. Graham Carlos, C. S. Dela Cruz, B. Cao, et al., "Novel Wuhan (2019-NCoV) coronavirus," American Journal of Respiratory and Critical Care Medicine, vol. 201, no. 4, pp. P7-P8, 2020, doi: 10.1164/rccm.2014P7.

[16] G. J. Rubin, S. Wessely, "The psychological effects of quarantining a city," BMJ, vol. 368, no. January, pp. 1-2, 2020. doi: https://doi.org/10.1136/bmj.m313.

[17] H. Nishiura, T. Kobayashi, Y. Yang, et al., "The Rate of Underascertainment of Novel Coronavirus (2019-nCoV) Infection : Estimation Using Japanese Passengers Data on Evacuation Flights," Journal Clinical Medicine, vol. 9, no. 2, p. 419, 2020, https://doi.org/10.3390/jcm9020419.

[18] B. D. Shigemura J, Ursano RJ, Morganstein JC, Kurosawa M., "Public responses to the novel 2019 coronavirus (2019-nCoV) in Japan: Mental health consequences and target populations," Psychiatry Clinical Neurosciences, vol. 74, no. 4, pp. 281-282, 2020. doi: 10.1111/pcn.12988

[19] L. Kang., et al., "Impact on mental health and perceptions of psychological care among medical and nursing staff in Wuhan during the 2019 novel coronavirus disease outbreak: A cross-sectional study," Brain, Behavior, and Immunity., vol. 87, pp. 1-7, 2020, doi: https://doi.org/10.1016/j.bbi.2020.03.028.

[20] J. G. Adams and R. M. Walls, "Supporting the Health Care Workforce during the COVID-19 Global Epidemic," J Journal of the American Medical Association., vol. 323, no. 15, no. 1439-1440, 2020. doi: 10.1001/jama.2020.3972.

[21] M. Mehta, M. M. Singh, S. K. Gupta, et al., "Study of Stress among Health Care Professionals: A Systemic Review," International Jourmal Research Foundation Hospital. Healthcare Administration, vol. 6, no. 1, pp. 6-11, 2018. doi: 10.5005/jp-journals-10035-1084.

[22] R. G. Maunder., et al., "Long-term Psychological and Occupational Effects of Providing Hospital Healthcare during SARS Outbreak.," Emerg Infect Dis., vol. 12, no. 12, pp. 1924-1932, 2006. doi: 10.3201/eid1212.060584.

[23] I. A. Khalid, I., Khalid, T. J., Qabajah, et al., "Healthcare Workers Emotions, Perceived Stressors and Coping Strategies During a MERS-CoV Outbreak," Clinical Medicine \& Research, vol. 14, no. 1, pp. 7-14, 2016.

[24] Worldometers, Total Coronavirus Cases in Indonesia, 2020. [Online]. Available: https://www.worldometers.info/coronavirus/country/indonesia/.

[25] W. Lu, H. Wang, Y. Lin, L. Li, "Psychological status of medical workforce during the COVID-19 pandemic: A cross-sectional study.," Psychiatry Research, vol. 288: 112936, 2020, doi: https://doi.org/10.1016/j.psychres.2020.112936.

[26] N. Sun, et al., "A Qualitative Study on the Psychological Experience of Caregivers of COVID-19 Patients," American Journal Infectious Control, vol. 48, no. 6, pp. 592-598, 2020.

[27] M. L. R. Neto et al., "When health professionals look death in the eye: the mental health of professionals who deal daily with the 2019 coronavirus outbreak," Psychiatry Research, vol. 288, pp. 2-4, 2020, doi: 10.1016/j.psychres.2020.112972.

[28] C. Wang, et al., "Immediate psychological responses and associated factors during the initial stage of the 2019 coronavirus disease (COVID-19) epidemic among the general population in China," International Journal Environmental Research Public Health, vol. 17, no. 5, p. 1729, 2020, doi:10.3390/ijerph17051729.

[29] Xiao C, "A Novel Approach of Consultation on 2019 Novel Coronavirus (COVID-19)-Related Psychological and Mental Problems: Structured Letter Therapy," Psychiatry Investig, vol. 17, no. 2, pp. 175-176, 2020, doi: 10.30773/pi.2020.0047.

[30] J. B. Nezlek, E. D. Wesselmann, L. Wheeler, and K. D. Williams, "Ostracism in everyday life," Gr. Dyne, vol. 16, no. 2, pp. 91-104, 2012, doi: 10.1037/a0028029.

[31] E. A. Troyer, J. N. Kohn, S. Hong, "Are we facing a crashing wave of neuropsychiatric sequelae of COVID-19? Neuropsychiatric symptoms and potential immunologic mechanisms," Brain, Behavior, and Immunity, vol. 87, pp. 34-39, 2020, doi: https://doi.org/10.1016/j.bbi.2020.04.027.

[32] W. D. Matua GA, "Living Under the Constant Threat of Ebola: A Phenomenological Study of Survivors and Family Caregivers During an Ebola Outbreak," Journal Nursing Research, vol. 23, no. 3, pp. 217-224, 2015.

[33] L. J. Liang Y,, Chen M., Zheng X., "Screening for Chinese medical staff mental health by SDS and SAS during the outbreak of COVID-19," Journal of Psychosomatic Research, vol. 133, no. 110102, 2020.

[34] S. M. Lee, W. S. Kang, A. R. Cho, et al.," "Psychological impact of the 2015 MERS outbreak on hospital workers and quarantined hemodialysis patients," Comprehensive Psychiatry vol. 87, pp. 123-127, 2018, doi: https://doi.org/10.1016/j.comppsych.2018.10.003. 